\title{
Use of camera-traps in natural trails and shelters for the mammalian survey in the Atlantic Forest
}

\author{
Geruza L. Melo ${ }^{1}$, Jonas Sponchiado ${ }^{2} \&$ Nilton C. Cáceres ${ }^{3}$
}

\footnotetext{
1. Programa de Pós-Graduação em Ecologia e Conservação, CCBS, Universidade Federal do Mato Grosso do Sul, Caixa Postal 549, Campo Grande, MS, 79070-900, Brazil. Corresponding author. (geruzalm@yahoo.com.br)

2. Programa de Pós-Graduação em Biodiversidade Animal, CCNE, Universidade Federal de Santa Maria, Camobi, Santa Maria, RS, 97110-970, Brazil.

3. Laboratório de Ecologia e Biogeografia, Departamento de Biologia, Universidade Federal de Santa Maria, Camobi, Santa Maria, RS, 97110-970, Brazil.
}

\begin{abstract}
In order to evaluate the efficiency of different mammalian survey methods, we compared traditional sampling techniques (use of camera-traps on roads and artificial trails, track censuses, and direct field visualization) with an alternative sampling design (camera-traps positioned in natural areas such as natural trails and shelters). We conducted the study in a deciduous Atlantic-Forest park in southern Brazil, and additionally compared our results with a previous intensive study carried out in the same area. Our considerably smaller sampling effort (example: 336 trap.day for our camera-traps versus 2,154 trap.day for the earlier study) registered the presence of 85\% of the local known species, with camera-traps being $68 \%$ efficient. Moreover, shelter camera-traps revealed a different species composition regarding most of other sampling methods. This sampling strategy involving natural forest sites was therefore able to effectively optimize the chances of evaluating species composition in a shorter period, especially with respect to lower-density and cryptic species, as well as to detect species that avoid open, disturbed sites such as roads and man-made forest trails.
\end{abstract}

KEYWORDS. Combined sampling, diversity evaluation, forest interior, trapping effort.

RESUMO. Utilização de armadilhas fotográficas em carreiros naturais e abrigos para amostragem de mamíferos da Mata Atlântica. A fim de avaliar a eficiência de vários métodos de levantamento de mamíferos, comparamos as técnicas de amostragem tradicionais (uso de armadilhas fotográficas nas estradas e trilhas artificiais, procura por pegadas, e visualização direta em campo) com um delineamento amostral alternativo (armadilhas fotográficas posicionados em áreas naturais, tais como carreiros naturais e abrigos). Realizamos o estudo em uma floresta estacional decidual no sul do Brasil, e comparamos nossos resultados com um estudo anterior intensivo realizado na mesma área. Nosso esforço amostral consideravelmente menor (exemplo: 336 armadilhas.dia para armadilhas fotográficas contra 2.154 armadilhas.dia no estudo anterior) registrou a presença de $85 \%$ das espécies previamente conhecidas para a área, com armadilhas fotográficas tendo $68 \%$ de eficiência. Além disso, as armadilhas fotográficas posicionadas em abrigos revelaram uma composição diferente de mamíferos em comparação com a maioria dos outros métodos de amostragem. Esta estratégia de amostragem que envolve locais de floresta natural foi, portanto, capaz de efetivamente otimizar as chances de avaliar a riqueza de espécies em um curto período, especialmente com relação a espécies crípticas e/ou de menor densidade, bem como detectar as espécies que evitam áreas abertas, como estradas e trilhas abertas pelo homem na floresta.

PALAVRAS-CHAVE. Combinação de métodos, avaliação da diversidade, interior de floresta, esforço amostral.

Mammal inventories are extremely important in improving our understanding of the geographical distribution of species on both large and small scales, and are therefore essential tools for conservation programs. There are several methods currently available with which to investigate the occurrence of medium and large mammal species present in an area, such as footprint identification (BIDER, 1968; CARRILLO et al., 2000), censuses (Cullen JR \& Rudran, 2003) and camera traps (Trolle, 2003; ToBler et al., 2008). Some studies have evaluated the efficiency of each method in assessing species richness (SilveIra et al., 2003; LYRA-JORGE et al., 2008). There is a general consensus that the concurrent application of several methods is recommended (Voss \& Emmons, 1996; SRbek-Araujo \& Chiarello, 2005), since the use of a single method may not be able to account for all the different species within an area. Line-transect censuses, for example, may not be able to detect rare species such as carnivores (PARDINI et al., 2004), while track counts are not reliable for some groups of closely-related species that have very similar tracks such as species of deer, wild pigs and small cats (Borges \& TomÁs, 2004).

The use of camera-traps in mammal surveys has been found to be one of the most effective methods for the inventorying of cryptic species rarely found by other survey techniques. However, in order to optimize this sampling method, it is essential that the sampling design be carefully studied and the areas chosen for the installation of traps cover a broad range of different habitats (Tomís \& MiRanda, 2003). In South America, camera-traps are commonly installed on man-made roads and trails inside protected areas and forest fragments, for mammalian survey (Trolle, 2003; KASPER et al., 2007; Srbek-Araujo \& Chiarello, 2007; Goulart et al., 2009) as well as single species abundance (e.g. big cats and canids; Tobler et al., 2008; Di BiтetTi et al., 2009; Harmsen et al., 2010). However, it is known that trapping effort performed only at such sites is biased to sample only those species that preferentially use these artificial trails and roads (HARMSEN et al., 2010). Other shy species are also likely to avoid these open, artificial sites in forests, moving preferentially in the forest interior. Thus sampling solely along roads or specific trails can lead to only a sub-sample of species abundance being searched, or even their complete absence from inventories.

Natural areas within dense forests should therefore be used together with man-made trails and natural trails for sampling mammal diversity, in order to increase the 
chances of sampling a wider range of species, reducing both the time and cost of sampling, as well as providing less biased results. Although not well understood (HARMSEn et al., 2010), natural paths and trails are used by various species to move between habitats within a forest, and thus the positioning of camera-traps at these sites should provide important results in terms of accurately assessing local diversity. The same principle can be applied to sites used as potential shelter by different species.

This study compares two camera-trap-based survey designs (installed in shelters and natural forest trails) recommended for the evaluation of Neotropical wild mammal diversity, with traditional survey methods and designs based on track recording, field visualization and camera-traps installed in man-made locations such as dirt roads. Besides this comparison, a second objective was to compare our smaller sampling effort (four months spread over a one year period) with that used in a previous study in the area, which involved an intensive two-year sampling protocol, but focusing on the comparative approach of the use of cameratraps in forest shelters and natural trails by us and the use of camera-traps in man-made roads and trails by the previous authors. We expected that camera-traps installed in natural trails and shelters will bring different data on species occurrence and relative abundance regarding traditional survey methods. Besides, we expected that our sampling design using natural trail camera-traps will not differ from results obtained in that previous study, except for shelter ones that will show a different mammal composition.
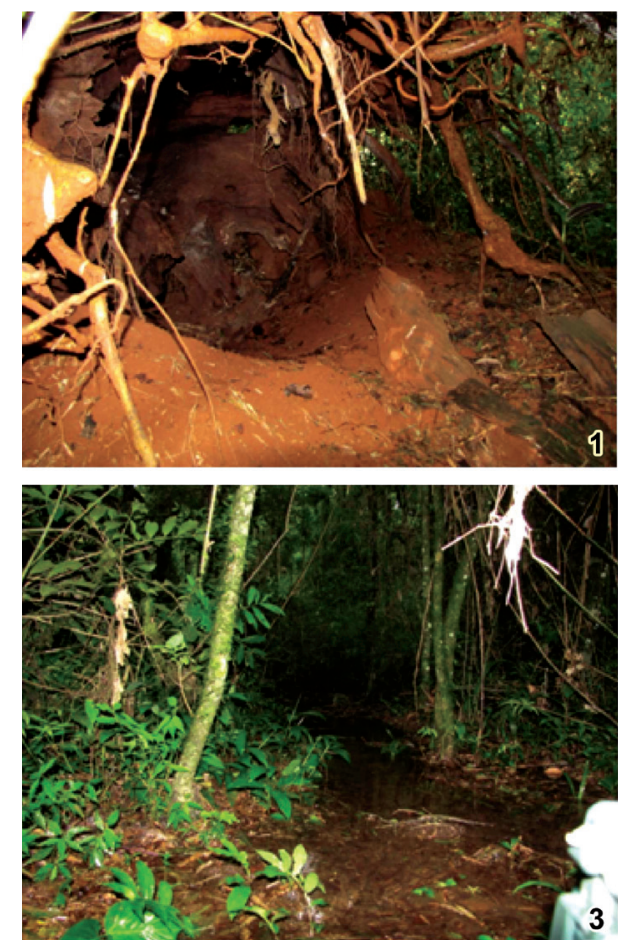

\section{MATERIALS AND METHODS}

Study area. The study was carried out in a deciduous forest in Parque Estadual do Turvo (PET; $27^{\circ} 00^{\prime} \mathrm{S}, 27^{\circ} 20^{\prime} \mathrm{S}$ and $53^{\circ} 40^{\prime} \mathrm{W}, 54^{\circ} 10^{\prime} \mathrm{W}$ ), located in the municipality of Derrubadas in northwestern Rio Grande do Sul, Brazil. PET is a Conservation Unit with an area of 17,491 ha and is connected to large, preserved areas of Atlantic forest in Argentina.

The climate is subtropical humid temperate, with hot summers (Cfa according to the Köppen classification). The mean temperature of the warmest month (January) is above $22^{\circ} \mathrm{C}$, while that of the coldest month (July) ranges from -3 to $18^{\circ} \mathrm{C}$. Rainfall is evenly distributed throughout the year, with an annual mean of 1,665 mm (SEMA, 2005).

The study was focused inside the park, excluding the edges and riverbanks which form its limits.

Trapping procedures. The study was carried out in four field phases: May, July, September and November 2009, with camera-traps monitored for 6 complete days in each field phase. Fourteen camera-traps were installed: seven in shelter sites and seven along natural trails inside the forest. Shelters took the form of sites formed by large rocks, fallen logs and tree roots thought to protect mammals from rain, wind, cold and sunlight (Figs 1,2). Natural trails were those passages inside the forest thought to facilitate movement of mammals (Figs 3,4). These probably also function as corridors between dense patches of forest and are not related to human construction. The camera-traps were installed at these sites with no bait and at an average height of $30 \mathrm{~cm}$
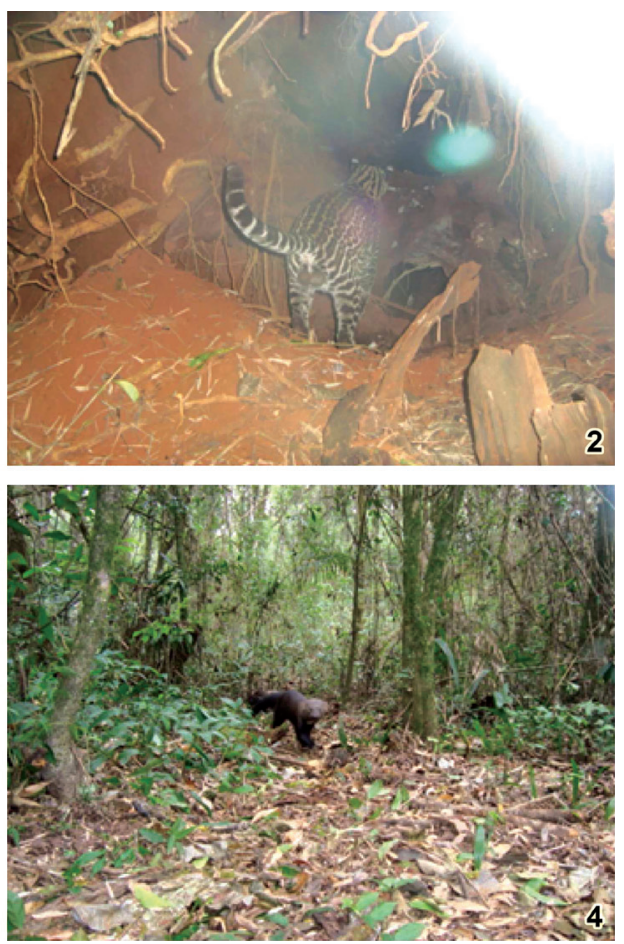

Figs 1-4. Camera-traps installed in Parque Estadual do Turvo, state of Rio Grande do Sul, southern Brazil. 1, Shelter formed by a fallen tree trunk; 2, Leopardus pardalis in the same shelter shown in figure 1; 3, natural trail inside the forest; 4, Eira barbara in the natural trail shown in figure 3. 
above the ground. Camera-traps at adjacent natural trail stations were placed at least $200 \mathrm{~m}$ apart and maximum of $1,850 \mathrm{~m}$ between paired stations (mean $=767 ; \mathrm{SD}=$ $715 \mathrm{~m}$ ), with a distance of at least $100 \mathrm{~m}$ between those at adjacent shelter stations (with a maximum of $1500 \mathrm{~m}$; mean $=740 ; \mathrm{SD}=555 \mathrm{~m}$ ). We estimate that our sampling covered about 5,200 ha of the park (around $30 \%$ of the total protected area), divided in two blocks of cameratrap stations, those installed in the western side $(3,600$ ha) and the eastern side (1,600 ha). For a comparative approach, we sampled in the same locations in the park as did KASPER et al. (2007), but with a slightly greater area sampled favouring the effort of these last authors.

The search for tracks was carried out along two dirt roads inside the park during a single day in each field phase. Each sample unit consisted of a transect line $(\mathrm{n}=12)$ measuring $400 \mathrm{~m}$ in length and was on average $360 \mathrm{~m}$ apart from adjacent ones. Thus we have sampled a total of $4.8 \mathrm{~km}$ of dirt roads inside the park, divided in 12 transect lines, which covered those $30 \%$ of the park area. Comparing with KASPER et al. (2007), we have sampled $19.2 \mathrm{~km}$ in total for tracks whereas these last authors have sampled a total of $128 \mathrm{~km}$.

Finally, diurnal visualization was undertaken for seven days in each phase. Visualizations were performed along the same two roads used in the search for tracks, as well as along twelve $250 \mathrm{~m}$-transect lines previously established in an earlier small-mammal survey (Melo et al., 2011).

In order to assess sampling efficiency, the results were also compared with those obtained previously by KASPER et al. (2007), who performed an intensive survey of non-flying mammals in the same study area. To make the comparison, semi-aquatic mammals were not considered since riverside areas were not sampled in the present study. Other species not considered included some belonging to difficult-to-identify groups, depending on the survey method used. Using certain survey techniques has previously led to erroneous species identification, such as for the genera Mazama and Leopardus and the species Herpailurus yagouaroundi (É. Geoffory Saint-Hilare, 1803). Thus for all three survey methods Mazama species were considered as a group, with the presence of either Mazama gouazoubira (Fischer, 1814) or M. americana (Erxleben, 1777) in an area not specified; secondly, the tracks of small species belonging to Leopardus and of H. yagouaroundi were not included, since their track identification is often not completely reliable (Borges \& TOMÁs, 2004); finally, since only Didelphis aurita (Wied-Neuwied, 1826) was considered to occur in forests of the interior of the Park based on an intensive capture program (Melo et al., 2011), all tracks identified as Didelphis were specified as belonging to $D$. aurita.

A comparison was also made between the respective survey and sampling design effort carried out here and that performed by KASPER et al. (2007), with a particular focus on the efficiency of each survey method based on area sampled (search for tracks and visualization) and sampling days (natural and artificial areas sampled using camera-traps). Analytical units used in this comparison included kilometer.month $(\mathrm{km}$. month; total $\mathrm{km}$ surveyed in one day multiplied by the number of days sampled) for track and visualization monitoring, and trap.day (number of traps installed in one day multiplied by the total of days sampled) for camera-trap usage.

Statistical Analyses. Considering only the data recorded in the present study, a frequency of occurrence for a given species was calculated for each survey method per sampling unit. This procedure involved calculating in how many months a given species was recorded, with the results ranging from 0 (no record) to 4 (occurrence in all of the four months sampled). After that, a Wilcoxon test for dependent data (based on species frequencies obtained from two paired methods) was run between visualization, track and (trail and shelter) camera-trap records in order to test the similarity in the results obtained between these sampling methods. Species frequencies in field phases were compared using the paired non-parametric test according to Tab. I.

The efficacy of each camera-trap design with respect to sampling effort was measured using a collector curve through the program Estimates 7.5 (Colwell, 2005), based on the addition of new species as a function of sampling days. Concomitantly, species richness was estimated using the Jack-knife 1 and Jackknife 2 estimators. In this case, the data obtained by shelter and natural trail camera-traps were considered separately in order to verify the efficiencies of both sampling methods.

Our results were also compared with the species richness and composition found by KASPER et al. (2007) provided that these authors have surveyed intensively the study area recently, and using similar sampling methods, except for differences in camera-trap usage. They have divided their time effort in two phases, the first one (camera-trap, track and visual monitoring) occurring only in the two roads of the park, and the second one with a more intensive effort extending the monitoring to forest trails made by them at short distances from the roads of the park. Unfortunately, the specific trapping effort undertaken and results for each place (forest trail, roads and other sites surveyed) and year were not mentioned separately. Thus the efficiency rates for each sampling method was evaluated by dividing our observed species richness by the richness found by KASPER et al. (2007), for a given sampling method.

To compare frequencies of each species between both studies, the Kolmogorov-Smirnov test was carried out, comparing our camera-trap relative abundance data with those of KASPER et al. (2007) in terms of trapping efficiency and discrepancies. Equally, the relative abundance recorded by our two camera-trap designs was 
tested by performing the Kolmogorov-Smirnov test. So species relative frequencies were compared in such nonparametric test according to Tab. II.

The Kolmogorov-Smirnov and Wilcoxon tests were run in the PAST version 1.97 statistical package (HAMMER et al., 2001).

\section{RESULTS}

Comparison involving our sampling methods. The sampling methods used in the present study resulted in the recording of a total richness of 17 mammal species. Trail camera-traps recorded the presence of 13 species, shelter camera-traps 5 species, track analysis 12 species and direct visualization 8 species (Tab. I).

All species observed by shelter-traps were also sampled using the other two sampling methods (trail and track), with the two camera-trap designs sampling 13 different species in total. Three species were found exclusively by trail camera-traps: Eira barbara (Linnaeus, 1758), H. yagouaroundi and Leopardus wiedii (Schinz, 1821). Track analysis revealed the presence of two species not found by any other method: Dasypus novemcinctus Linnaeus, 1758 and Procyon cancrivorus (G. [Baron] Cuvier, 1798), as well as one species ( $D$. aurita; see Methods) not found by either camera-trap method but observed via direct visualization. Alouatta guariba (Humboldt, 1812) was the only species observed exclusively by direct visualization (Tab. I).

The Wilcoxon test revealed significant differences for frequencies between trail and shelter camera-traps $(\mathrm{W}=66 ; \mathrm{n}=17$ species; $\mathrm{p}=0.003)$ and shelter cameratraps and tracks $(\mathrm{W}=55 ; \mathrm{n}=17 ; \mathrm{p}=0.004)$. However, no significant differences were found between trail camera-traps and tracks $(\mathrm{W}=78.5 ; \mathrm{n}=17 ; \mathrm{p}=0.095)$, trail camera-traps and visualizations $(\mathrm{W}=72.5 ; \mathrm{n}=17$ species; $p=0.054)$, nor between shelter camera-traps and visualizations $(\mathrm{W}=32 ; \mathrm{n}=17 ; \mathrm{p}=0.250$ ).

There was a significant difference between the data obtained via the two camera-trap sampling designs (shelter and trail) used in our study ( $\mathrm{D}=0.42, \mathrm{n}=19$ species, $\mathrm{p}=0.049)$. Despite that, species with similar relative abundances were Nasua nasua (Linnaeus, 1766), Leopardus pardalis (Linnaeus, 1758) and Dasyprocta azarae Lichtenstein, 1823(the highest frequency values) while Pecari tajacu (Linnaeus, 1758) had the highest discrepancy in relative values (Tab. I).

The collector curve (Fig. 5) reveals that the rate of species accumulation, as well as the estimated richness, was greater for camera-traps installed along trails than at those in shelters. The curve based on data obtained from camera-traps placed in shelters trends towards stabilization, with a small standard deviation $(\mathrm{SD}=$ 0.66 ). However, the species accumulation curve based on the results from traps placed along natural trails is far from reaching the asymptote $(\mathrm{SD}=2.81)$. Expected richness values for trail camera-traps was $19.0 \pm 1.30$ (SD) species for Jackknife 1 and $24.0 \pm 0.0$ for Jackknife 2. In contrast, the expected species richness of data obtained via the use of shelter camera-traps was lower: $5.9 \pm 0.9$ species for Jackknife 1 and $6.0 \pm 0$ species for Jackknife 2.

Comparison with the previous survey. The total effort expended in this study was 336 trap.day compared to 2,154 used by KASPER et al. (2007). In terms of track recording, our effort was $19.2 \mathrm{~km}$.month, far less than

Tab. I. Species recorded via different methods in Parque Estadual do Turvo, state of Rio Grande do Sul, southern Brazil. Numbers represent the number of field phases (maximum is four) in which a given species was recorded.

\begin{tabular}{|c|c|c|c|c|c|}
\hline Order & Species & Trail & Shelter & Track & Visualization \\
\hline Didelphimorphia & Didelphis aurita & 0 & 0 & 1 & 1 \\
\hline Cingulata & Dasypus novemcinctus & 0 & 0 & 4 & 0 \\
\hline \multirow[t]{2}{*}{ Primates } & Alouatta guariba & 0 & 0 & 0 & 1 \\
\hline & Cebus nigritus & 1 & 0 & 0 & 2 \\
\hline \multirow[t]{8}{*}{ Carnivora } & Nasua nasua & 3 & 2 & 4 & 2 \\
\hline & Procyon cancrivorus & 0 & 0 & 2 & 0 \\
\hline & Eira barbara & 1 & 0 & 0 & 0 \\
\hline & Cerdocyon thous & 1 & 0 & 3 & 1 \\
\hline & Leopardus wiedii & 1 & 0 & 0 & 0 \\
\hline & Leopardus pardalis & 3 & 3 & 3 & 0 \\
\hline & Panthera onca & 1 & 0 & 2 & 0 \\
\hline & Puma yagouaroundi & 1 & 0 & 0 & 1 \\
\hline \multirow[t]{2}{*}{ Artiodactyla } & Mazama spp. & 2 & 0 & 4 & 0 \\
\hline & Pecari tajacu & 3 & 1 & 4 & 2 \\
\hline Perissodactyla & Tapirus terrestris & 3 & 2 & 4 & 0 \\
\hline Rodentia & Dasyprocta azarae & 4 & 4 & 4 & 3 \\
\hline Lagomorpha & Sylvilagus brasiliensis & 1 & 0 & 3 & 0 \\
\hline
\end{tabular}


Tab. II. Number of photographic records of species obtained by camera-traps installed in two different habitats (natural trail and shelter) in Parque Estadual do Turvo, state of Rio Grande do Sul, southern Brazil. New records of a given species obtained by the same camera-trap were considered only after an hour's interval. The camera-trap results of Kasper et al. (2007) are shown for comparison. Relative frequencies are in parentheses.

\begin{tabular}{|c|c|c|c|c|c|c|c|}
\hline Order & Species & & Trail & & Shelter & & SPER et al. \\
\hline Didelphimorphia & Didelphis aurita & 0 & $(0.00)$ & 0 & $(0.00)$ & 11 & $(0.01)$ \\
\hline Cingulata & Dasypus novemcinctus & 0 & $(0.00)$ & 0 & $(0.00)$ & 8 & $(0.01)$ \\
\hline Pilosa & Tamandua tetradactyla & 0 & $(0.00)$ & 0 & $(0.00)$ & 3 & $(0.00)$ \\
\hline Primates & Cebus nigritus & 1 & $(0.02)$ & 0 & $(0.00)$ & 3 & $(0.00)$ \\
\hline \multirow[t]{10}{*}{ Carnivora } & Nasua nasua & 7 & $(0.11)$ & 5 & $(0.33)$ & 82 & $(0.05)$ \\
\hline & Procyon cancrivorus & 0 & $(0.00)$ & 0 & $(0.00)$ & 51 & $(0.03)$ \\
\hline & Eira barbara & 1 & $(0.02)$ & 0 & $(0.00)$ & 16 & $(0.01)$ \\
\hline & Cerdocyon thous & 1 & $(0.02)$ & 0 & $(0.00)$ & 65 & $(0.04)$ \\
\hline & Leopardus wiedii & 1 & $(0.02)$ & 0 & $(0.00)$ & 1 & $(0.00)$ \\
\hline & Leopardus tigrinus & 0 & $(0.00)$ & 0 & $(0.00)$ & 1 & $(0.00)$ \\
\hline & Leopardus pardalis & 5 & $(0.08)$ & 7 & $(0.47)$ & 211 & $(0.13)$ \\
\hline & Panthera onca & 1 & $(0.02)$ & 0 & $(0.00)$ & 4 & $(0.00)$ \\
\hline & Puma concolor & 0 & $(0.00)$ & 0 & $(0.00)$ & 5 & $(0.00)$ \\
\hline & Puma yagouaroundi & 1 & $(0.02)$ & 0 & $(0.00)$ & 27 & $(0.02)$ \\
\hline \multirow[t]{2}{*}{ Artiodactyla } & Mazama spp. & 5 & $(0.08)$ & 0 & $(0.00)$ & 44 & $(0.03)$ \\
\hline & Pecari tajacu & 18 & $(0.28)$ & 1 & $(0.07)$ & 196 & $(0.12)$ \\
\hline Perissodactyla & Tapirus terrestris & 6 & $(0.09)$ & 2 & $(0.07)$ & 99 & $(0.06)$ \\
\hline Rodentia & Dasyprocta azarae & 17 & $(0.26)$ & 28 & $(0.07)$ & 432 & $(0.27)$ \\
\hline Lagomorpha & Sylvilagus brasiliensis & 1 & $(0.02)$ & 0 & $(0.00)$ & 334 & $(0.21)$ \\
\hline
\end{tabular}

the $1,152 \mathrm{~km}$.month of the previously cited authors. This ratio of effort between the two studies was maintained with respect to the visualization method of sampling.

All species surveyed by camera-traps in the present study were also recorded by KASPER et al. (2007). The latter study sampled 20 species in total (excluding semiaquatic and open-habitat species; see Methods) with 19 recorded by camera-trap, 14 by track analysis and 14 by direct visualization in the field. Comparing the recording of species richness in our investigation with that of the previous study, the efficiency rates for each method were $68.4 \%$ for camera-trap, $85.7 \%$ for track recording, $57.1 \%$ for direct visualization, and $85.0 \%$ when all methods are considered together (based on results shown in Tab. II).

The Kolmogorov-Smirnov test revealed that the installation of camera-traps along natural trails in the present study brought similar quantitative results in terms of surveillance of the mammal community when compared to those of KASPER et al. (2007) ( $\mathrm{D}=0.16$; $\mathrm{n}$ $=19$ species; $p=0.956)$. In contrast and as expected, there was no similarity between our results obtained through camera-traps installed in shelters and those of KASPER et al. (2007) installed in man-made trails ( $\mathrm{D}=$ $0.42 ; \mathrm{n}=19$ species; $\mathrm{p}=0.049$ ). There were 14 mammal species absent from our shelter camera-traps regarding the 19 species recorded by previous study in the park, with emphasis for small species such as small cats, $E$. barbara, Silvilagus brasiliensis (Linnaeus, 1758), and the opossum D. aurita (Tab. II).

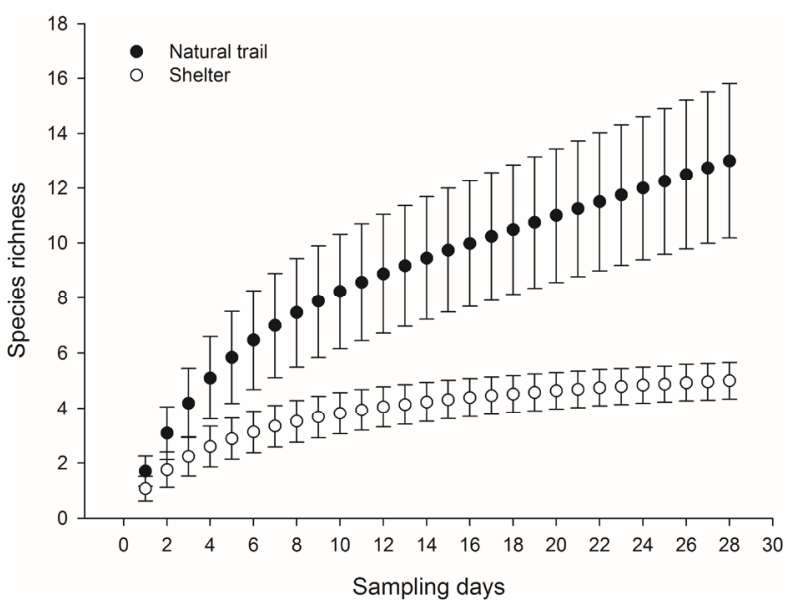

Fig. 5. Species accumulation curve (collector curve) for camera-traps installed in shelters and trails in Parque Estadual do Turvo, state of Rio Grande do Sul, southern Brazil.

\section{DISCUSSION}

We showed here that, for mammalian survey, the camera-traps should not only be installed along artificial trails, but also in natural forest trails and shelters for the reason explained below. Given that our results on natural trails comparing with those from man-made trails, tracks and visualizations were similar, natural trails are easy to find in the forest interior and save time and effort by avoiding making artificial trails. Although 
shelter availability is high in forests, our results point that shelter camera-traps are potentially a good sampling strategy to survey mammalian diversity, provided that they bring different faunal composition, as we have shown.

However, we pointed out that, even in our study, camera-traps were not placed along all types of trails and shelters used by the local mammal fauna, and thus only a part of the local community was sampled. This is particularly true for shelter camera-traps, for which we believe that the shelter availability in the forest is high, given the high diversity of mammals of different body size and adaptation that dwell in the Atlantic Forest (Emmons \& Feer, 1997). Considering their objectives, future studies producing similar mammal inventories should therefore ideally locate and sample as many types of trail and particularly shelter as possible. For example, it should be emphasized that ecological studies of Neotropical mammals involving investigation of natural trails and shelters are scarce, and thus further research proposals would contribute much to the knowledge of ecological relationships of mammals with the environment. The fact that we did not use bait strengthens our results, since the animals were photographed without being intentionally attracted to the cameras.

The estimate obtained by Jackknife 2 for the data obtained by natural-trail camera-traps resulted in a species richness value similar to that obtained by KASPER et al. (2007), but with a smaller sampling effort. Our conclusion, based on the comparison with both the previous study in the study area and the literature, is that sampling the forest interior via the placement of camera-trap tends to provide a better sample of diversity at low cost, and is also less biased with regard to the sampling of a number of common (e.g. Cerdocyon thous (Linnaeus, 1766), D. azarae and S. brasiliensis) or large species that frequently use dirt roads or large man-made trails to move (KASPER et al., 2007; Goulart et al., 2009). For example, the track analysis method tends to underestimate the presence of certain groups of species such as the small wild cats and forest deer, since these animals are difficult to identify to species level - in most cases due to the similarity of their tracks (BORGES $\&$ ToмÁs, 2004). In contrast, camera-traps, especially when installed inside a forest and along natural paths, are able to sample species rarely found in more open environments (such as dirt roads) or disturbed areas. This could be seen by analyzing the GoUlart et al. (2009) study in which rare forest species (such as E. barbara, $L$. wiedii and $H$. yagouaroundi) tended to be recorded only on small, narrow (although artificial) trails inserted in the forest interior. As emphasized here, sampling in areas within tropical forests can reveal previously unknown patterns of biological diversity or abundance, as observed by Oliveira-SANTOS et al. (2008) who sampled a different guild of mammals through the use of camera-traps installed in tree branches. The behavior and ecology of such cryptic species will be revealed with the help of camera-traps or other survey devices installed in different and appropriated natural trails and shelters.

In order to obtain an accurate sample of the species richness of an area, it is often necessary to expend a large sampling effort (Voss \& Emmons, 1996) which can lead to an increase in overall project costs (due to extended project duration and/or the use of more field equipment). Comparing some previous studies, SRBEKAraujo \& Chiarello (2005) found $81 \%$ of species at Santa Lucia Biological Station, Brazil, with an effort of 1,849 trap.day; and ToBler et al. (2008) observed $75 \%$ and $86 \%$ of known species in two field phases in an Amazon Forest in Peru, with sampling efforts of 1,440 and 2,340 trap.day, respectively. In contrast, in our study we identified $68.4 \%$ of all mammal species known to occur at PET using camera-traps placed in strategic areas, despite our small sampling effort (336 trap.day). Furthermore, the projection of the produced collector curve suggests that a doubling of our field effort would result in recording the total known species richness of the park. These numbers are thought to reinforce our proposed sampling methodology of using monitoring devices such as camera-traps in natural sites of forests, in addition to other sampling methods, since forest interiors have been neglected as the sites for installation of such field equipments in the Atlantic Forest.

We have shown that the installation of cameratraps, covering different natural forest areas such as trails and shelters, can result in a more efficient mammalian survey in terms of time, equipment and costs. In the forest interior, sampling design should be elaborated appropriately by choosing different types of natural trails and shelter to better identify those species that are related to each habitat and their frequency of occupancy, a subject that is still poorly understood for tropical terrestrial mammals (HARMSEN et al., 2010).

Acknowledgements. Our thanks go to colleagues at the Laboratório de Ecologia e Biogeografia of the Universidade Federal de Santa Maria: Arielli Machado, Brisa Peres, Cristiane Marks, Dinah Pathek and Franchesco Della Flora whose help with fieldwork was essential to this study. Thanks also go to the staff of the PET for the provision of logistical support, to Capes for the award of a scholarship to the first author and to $\mathrm{CNPq}$ for financial support given to NCC (Edital 06/2008 - Jovens Pesquisadores, Processo 569182/2008-5). NCC is a CNPqresearch fellow.

\section{REFERENCES}

BIDER, J. R. 1968. Animal activity in uncontrolled terrestrial communities as determined by sand transect technique. Ecological Monographs 38(4):269-308.

Borges, P. A. \& TomÁs, W. M. 2004. Guia de rastros e outros vestígios de mamíferos do Pantanal. Corumbá, Embrapa Pantanal. 148p.

Carrillo, E.; Wong, G. \& Cuarón, A. D. 2000. Monitoring mammal populations in Costa Rican protected areas under different hunting restrictions. Conservation Biology 14(6):1580-1591. 
Colwell, R. K. 2005. EstimateS: Statistical estimation of species richness and shared species from samples. Version 7.5. Available at: $<$ http://viceroy.eeb.unconn.edu/estimates $>$. Accessed on November 10, 2010.

Cullen JR., L. \& RudRan, R. 2003. Transectos lineares na estimativa de densidade de mamíferos e aves de médio e grande porte. In: Cullen JR., L.; R. Rudran, R. \& Valladares-Padua, C. eds. Métodos de estudos em biologia da conservação e manejo da vida silvestre. Curitiba, Editora da Universidade Federal do Paraná. p.169-179.

Di Bitetti, M. S.; Di Blanco, Y. E.; Pereira, J. A.; Paviolo, A. \& PÉREZ, I. J. 2009. Time partitioning favors the coexistence of sympatric crab-eating foxes (Cerdocyon thous) and pampas foxes (Lycalopex gymnocercus). Journal of Mammalogy 90:479-490.

Emmons, L. H. \& Feer, F. 1997. Neotropical rainforest mammals: a field guide. Chicago, University of Chicago. 396p.

Goulart, F. V. B.; Cáceres, N. C.; Graipel, M. E.; Tortato, M.; Ghizoni-JR, I. R. \& Oliveira-Santos, L. G. 2009. Habitat selection by large mammals in a southern Brazilian Atlantic Forest. Mammalian Biology 74(3):182-190.

HAMmer, Ø.; HAPER, D. A. T. \& RYAN, P. D. 2001. Past: paleontological statistics software package for education and data analysis. Palaeontologia Electronica 4:4-9.

Harmsen, B. J.; Foster, R. J.; Silver, S.; Ostro, L. \& Doncaster, C. P. 2010. Differential use of trails by forest mammals and the implications for camera trap studies, a case study from Belize. Biotropica 42(1):126-133.

Kasper, C. B.; Mazim, F. D.; Soares, J. B. G.; Oliveira, T. G. \& Fabián, M. E. 2007. Composição e abundância relativa dos mamíferos de médio e grande porte no Parque Estadual do Turvo, Rio Grande do Sul, Brasil. Revista Brasileira de Zoologia 24(4):1087-1100.

Lyra-Jorge, M. C. Ciocheti, G.; Pivello, V. R. \& Meirelles, S. T. 2008. Comparing methods for sampling large- and medium-sized mammals: camera traps and track plots. European Journal of Wildlife Research 54(4):739-744.

Melo, G. L.; Sponchiado, J.; Machado, A. F. \& Cáceres, N. C. 2011. Small-mammal community structure in a South American deciduous Atlantic Forest. Community Ecology 12(1):58-66.
Oliveira-Santos, L. G. R.; Tortato, M. A. \& Graipel, M. E. 2008. Activity pattern of Atlantic Forest small arboreal mammals as revealed by camera traps. Journal of Tropical Ecology 24(5):563-567.

Pardini, R.; Ditt, E. H.; Cullen, L.; Bassi, C. \& Rudran, R. 2004. Levantamento rápido de mamíferos terrestres de médio e grande porte. In: Cullen JR., L.; Rudran, R. \& Valladares-Padua, C. eds. Métodos de estudos em biologia da conservação e manejo da vida silvestre. Curitiba, Editora da Universidade Federal do Paraná. p.181-201.

SEMA - Secretaria Estadual do Meio Ambiente. 2005. Plano de Manejo do Parque Estadual do Turvo. Porto Alegre, Estado do Rio Grande do Sul. [s.n.]. 348p.

Silveira, L.; Jácomo, A. T. A. \& Diniz-Filho, J. A. F. 2003. Camera trap, line transect census and track surveys: a comparative evaluation. Biological Conservation 114(3):351-355.

Srbek-Araujo, A. C. \& Chiarello, A. G. 2005. Is camera-trapping an efficient method for surveying mammals in Neotropical forests? A study case in southeastern Brazil. Journal of Tropical Ecology 21(1):121-125

2007. Armadilhas fotográficas na amostragem de mamíferos: considerações metodológicas e comparação de equipamentos. Revista Brasileira de Zoologia 24(3):647-656.

Tobler, M. W.; Carrillo-Percastegui, S. E.; Pitman, R. L.; Mares, R. \& Powell, G. 2008. An evaluation of camera traps for inventorying large and medium sized terrestrial rainforest mammals. Animal Conservation 11(3):169-178.

Tomás, W. M. \& Miranda, G. H. B. 2003. Uso de armadilhas fotográficas em levantamentos populacionais. In: Cullen JR., L.; R. Rudran, R. \& Valladares-Padua, C. eds. Métodos de estudos em biologia da conservação e manejo da vida silvestre. Curitiba, Editora da Universidade Federal do Paraná. p.243-268.

Trolle, M. 2003. Mammal survey in the southeastern pantanal, Brazil. Biodiversity Conservation 12(4):823-836.

Voss, R. S. \& Emmons, L. H. 1996. Mammalian diversity in neotropical lowland rainforests: a preliminary assessment. Bulletin of American Museum of Natural History 230:1-115. 